\title{
Tělesná výchova v kurikulu Anglie: komparace s RVP ZV ${ }^{1}$
}

\author{
Michal Lupač \\ Masarykova univerzita, Pedagogická fakulta, Katedra tělesné výchovy a výchovy ke zdraví
}

Redakci zasláno 16. 3. 2019 / upravená verze obdržena 12. 5. 2019 /

/ k uveřejnění přijato 29. 6. 2019

\begin{abstract}
Abstrakt: Příspěvek je zaměřen na analýzu projektovaného kurikula tělesné výchovy (TV) v Anglii a jeho porovnání s RVP ZV z hlediska koncepce TV, cílů, vzdělávacího obsahu a vybraných kvalit kurikulárních dokumentů, kterými jsou návodnost a vnitřní koherence. Pro zasazení problematiky do širšího kontextu nabízí př́íspěvek stručný exkurz do vzdělávacího systému v Anglii. Výběr státu se opírá o Naulovo vymezení koncepcí TV (2011, s. 9), podle kterého koncepce TV v Anglii inklinuje ke sportovní koncepci. Naul však pracuje s daty z 90 . let, proto je jedním z cílů ověřit, zda je toto koncepční směřování nadále platné. Výzkum byl designován na základě problémového přístupu s využitím metody komparace. Pro sběr dat byla využita obsahová analýza textů. Výsledky naznačují, že vzdělávací obsah anglického kurikula vykazuje silné směřování ke sportovní koncepci TV. To je však v mírném rozporu s cíli TV, které sice rovněž částečně směřují ke sportovní koncepci, ale jsou značně postojové a ještě výrazněji směřují k celoživotní pohybové aktivitě. Tato nesourodost ovlivňuje míru vnitřní koherence. Cíle jsou v anglickém kurikulu TV definovány velmi obecně, dále jsou jen velmi málo rozpracovány a některé z nich nejsou podpořeny adekvátním vzdělávacím obsahem. Z hlediska návodnosti proto můžeme konstatovat, že anglické kurikulum TV je na nižší úrovni než RVP ZV. Při porovnání vzdělávacího obsahu vyplynulo, že učivo v českém kurikulu je širší a hlubší.
\end{abstract}

Klíčová slova: Anglie, kurikulum, tělesná výchova, návodnost, vnitřní koherence, komparace

Ke zdraví obyvatelstva se ve vyspělých státech s narůstajícím výskytem civilizačních chorob obrací stále větší pozornost nejen odborníků, ale též politiků. Jednou z těchto nemocí je obezita, která je negativním faktorem ovlivňujícím vznik dalších chronických onemocnění, jako jsou kardiovaskulární choroby, cukrovka nebo rakovina (WHO, 2018). Obezita je definována pomocí ukazatele BMI, který je zjištován na základě poměru tělesné váhy v kilogramech

1 Tento příspěvek vznikl s podporou projektu specifického výzkumu MUNI/A/0877/2017 Výzkum kurikula tělesné výchovy a výchovy ke zdraví realizovaného na Pedagogické fakultě Masarykovy univerzity. 
a výšky v metrech na druhou. Zatímco dříve byla obezita identifikována jako zdravotní problém vyspělých států, v současnosti se čím dál více objevuje rovněž ve státech s nízkými a průměrnými př́ijmy obyvatelstva.

Podle Světové zdravotnické organizace mělo v roce 2014 každé třetí jedenáctileté dítě v Evropě nadváhu nebo bylo obézní (WHO, 2014), podle dat z r. 2013 mělo více než 50 \% Evropanů nadváhu, z toho více než $20 \%$ bylo obézních (WHO, 2013, 2016, 2017).

Zaměříme-li se na obyvatele Anglie, dojdeme k podobným číslům. Podle statistik NHS Digital (2018) se od r. 1993 zvýšil počet obézních dospělých z $15 \%$ na $26 \%$, obézních dětí ve věku šesti let je pak $20 \%$. Zpráva dále uvádí, že počet obézních dospělých se ustálil na 25-27 \% již od roku 2010, což je však stále nad průměrem zemí OECD, který se drží lehce pod 20 \%. Dalších $35 \%$ obyvatel má nadváhu.

Z tohoto důvodu nejen Anglie, ale také další vyspělé státy častěji hledají způsoby, jak s obezitou a nadváhou bojovat.

V Anglii r. 2011 publikovala $\mathrm{CMO}^{2}$ směrnice, ve kterých udává doporučené denní dávky pohybu pro všechny věkové kategorie. V r. 2015 vydala britská vláda strategický dokument Sporting future s podtitulem $A$ new strategy for an active nation (HM Government, 2015). Tento dokument zaměřuje svou pozornost především na benefity, které sport přináší společnosti a státu. Ty měří pomocí míry dopadu na konkrétní výstupy: fyzickou pohodu ${ }^{3}$, psychickou pohodu, individuální rozvoj, sociální a společenský rozvoj a ekonomický rozvoj. Vedle toho tento dokument v menší míře uznává hodnotu získávání olympijských a paralympijských medailí (HM Government, 2015, s. 16), což odkazuje na silnou sportovní tradici britské společnosti. ${ }^{4}$ Mezi další způsoby, jakými mohou státy bojovat s nadváhou, obezitou a jejich nežádoucími vlivy, patří pochopení aktivního životního stylu jako jednoho z prostředků pro podporu tělesného zdraví obyvatelstva. Toho se politické elity a odborníci snaží docílit mj. v rámci kurikula školní tělesné výchovy (TV) začleňováním cílů a vzdělávacích obsahů vedoucích k celoživotní pohybové aktivitě. Naul (2003, s. 49; 2011, s. 9) uvádí, že v kurikulárních dokumentech Velké Británie

\footnotetext{
Chief Medical Office. Jedná se o britskou obdobu České lékařské komory.

3 Na jiném místě se však hovoří o tělesném a psychickém zdraví (srov. HM Government, 2015, s. 9); na podporu a důležitost zdraví je odkazováno též na mnoha dalších místech (HM Government, 2015, s. 14, s. 27, aj.).

4 Která se, jak ukazujeme níže, silně promítá i do anglického kurikula tělesné výchovy.
} 
vydaných $\mathrm{v} 90$. letech minulého století byla v rámci TV zachycena sportovní koncepce TV. Na to částečně odkazuje i výše zmíněný strategický dokument, avšak jeho další části i směrnice CMO naznačují, že si je britská společnost vedle důležitosti sportovních výsledků na mezinárodních kláních vědoma také důležitosti dopadu pohybové aktivity na zdraví obyvatelstva. Otázkou zůstává, zda se toto uvědomění promítá i do vzdělávání, které hraje zásadní roli v každé snaze o dlouhodobou změnu postojů a hodnot ve společnosti.

Abychom ověřili aktuální konceptuální směřování kurikulárního dokumentu TV v Anglii a rovněž jeho přínos pro inspiraci při současných revizích RVP ZV, rozhodli jsme se pro jeho analýzu na úrovni ISCED 1.

\section{K vybraným výzkumům řešené problematiky a cíli příspěvku}

Předložená studie je součástí disertačního výzkumu autora. Svou strukturou a částečně i použitou metodikou výzkumu navazuje na dřívější práce dalších autorů (srov. Habrdlová, Lupač, \& Vlček, 2017; Habrdlová \& Vlček, 2015; Lupač, 2016, 2018; Vlček \& Janík, 2010) a doplňuje analýzy kurikulárních dokumentů TV dalších evropských států, které Naul zahrnul do svého vektorového diagramu koncepcí TV (2011, s. 9). Část, která se věnuje relevantním výzkumům, zahrnuje práce, které jsme již rozebrali v našem předchozím textu (Habrdlová et al., 2017, s. 450-451), a proto jejich výsledky shrneme jen stručně. Do rešerše rovněž přidáváme studii Hoffmanna, Brixiusové a Vogta (2018), která byla vydána později. Pro úplnost dodejme, že relativně úzkými kritérii pro výběr studií bylo „zaměření prací na kurikulum TV, alespoň částečná orientace na primární vzdělávání, publikování výzkumů v uplynulé dekádě a dostatek informací o použité metodologii výzkumu" (Habrdlová et al., 2017, s. 450).

\subsection{Shrnutí vybraných výzkumů řešené problematiky}

Studie, které jsme do přehledu dle kritérií zařadili, docházejí k závěrům, jež jsou do značné míry podobné a které můžeme zasadit do vzájemných souvislostí. Dochází tak k logickému sledu jevů a jejich důsledků, které můžeme na určitých místech celého procesu vzdělávání ovlivnit.

Implementací pálkových her do výuky na 1. stupni v Německu se zabývali Hoffmann a kol. (2018). Do jejich výzkumu se zapojilo 498 učitelů, kterým 
byl zaslán standardizovaný dotazník s uzavřenými i otevřenými otázkami. Autoři mj. zjistili, že míru zařazování pálkových her do výuky ovlivňuje skladba volnočasových aktivit učitelů TV, jejich pracovní zkušenosti a dosažený stupeň vzdělání.

Jin (2013) zjistil rozpory mezi kurikulem projektovaným a realizovaným. Mezi zamýšleným a realizovaným kurikulem zjistil nesoulad i Annerstedt (2008). Zhu, Ennis a Chen (2011) došli k závěru, že míru propojení projektované a realizované formy kurikula ovlivňují kontextuální faktory konkrétní školy a preference a hodnotový systém učitele. Rossi a kol. (2009) pak přidávají další z důvodů, které za nesouladem mezi projektovanou a realizovanou formou kurikula mohou stát. Zjišt'ují, že zamýšlené významy a rétorika projektovaného kurikula se promítají do míry jeho (ne)pochopení, což opět může ovlivnit jeho realizaci ve školní praxi. Kougioumtzis (2014) pak mj. zjistil, že konkrétně ve švédském kurikulu existuje koncepční nesoulad mezi projektovanou a efektovou formou kurikula.

Ve výše uvedeném přehledu jsme záměrně neuvedli státy, jejichž projektovaných kurikul se zmíněná zjištění týkají. Snažíme se tím nezastínit skutečnost, že transfer (tedy určitý proces) zamýšleného obsahu a původní ideje mezi jednotlivými formami kurikula není nikdy bezchybný ${ }^{5}$ a během své cesty přes jednotlivé formy kurikula se stále více zkresluje. Z uvedených studií můžeme soudit, že míra zkreslení přenosu je ovlivněna určitými faktory, které do procesu vstupují (srov. Egger et al., 2002, s. 13-16). Z hlediska přenosu z projektované do realizované formy jsme uvedli kontextuální faktory školy, hodnotový systém učitele, jeho vlastní zájmové preference a zmínili jsme rovněž zamýšlené významy a rétoriku projektovaného kurikula. Docházíme proto k závěru, že kvalitu transferu mezi zmíněnými dvěma formami kurikula ovlivňuje kvalita vstupů, které se na transferu podílejí. Mezi ně můžeme bezesporu zařadit kurikulární dokumenty, které se z tohoto důvodu ocitly ve středu naší pozornosti.

Uvědomujeme si fatálnost užití slova „nikdy“ a skutečnost, že ve vědeckém diskurzu jej v této souvislosti můžeme použít až po erudovaném výzkumu všech světových kurikul a kvality transferu mezi jeho jednotlivými formami. Přesto zastáváme názor, že z důvodu vstupu vysokého množství faktorů a individuálních přístupů jednotlivých aktérů vzdělávání je prakticky nemožné, aby se zamýšlené kurikulum přesně $v$ jeho původní podobě přeneslo až do efektové formy. Na nesoulad mezi projektovanou a realizovanou formou upozorňuje ve své stati o neutěšeném postavení TV v mnoha evropských státech např. Crum (2017, s. 239). 


\subsection{Cíl príspěvku}

Smyslem analýzy je podrobit projektované kurikulum TV zkoumání z hlediska cílů a vzdělávacího obsahu s přihlédnutím k problémovým tématům vnitřní koherence a návodnosti dokumentu, která ovlivňují jeho kvalitu. Vnitřní koherenci chápeme jako „obsahové provázání cílů, vzdělávacích obsahů (učiva a příp. očekávaných výstupů) a standardů v projektovaném kurikulu" (Lupač, 2018, s. 27). Návodnost vymezujeme jako vlastnost dokumentu, která „učitelům usnadňuje jeho použití v praxi - nejedná se tedy o srozumitelnost vzhledem k laické, ale odborné veřejnosti, pro kterou jsou vzdělávací dokumenty primárně určeny" (Lupač, 2018, s. 26). Pro bližší vymezení témat odkazujeme čtenáře na výše citovanou práci.

Zaměření na kvalitativní témata souvisí s problematickou implementací českého RVP ZV (srov. např. Janík et al., 2010; Janík, Mužík, \& Vlček, 2016), jehož zavedení v r. 2005 nebylo již v počátcích reformy, jejímž dílčím výsledkem dokument byl, dostatečně prodiskutováno a zdůvodněno (Šíp, 2014, s. 4). Kladli jsme si otázku, zda jedním z důvodů vlažného přijetí RVP ZV může být i jeho kvalita. ${ }^{6}$

Zaměření na koncepci TV se v hledáčku našeho zájmu objevilo především z důvodu nízké úrovně kongruence mezi zamýšleným, projektovaným a realizovaným kurikulem TV v Česku, která plyne z problematické vnitřní koherence projektovaného kurikula (srov. Lupač, 2016, 2018; Habrdlová et al., 2017), které má za následek nejasnou koncepci TV v českém projektovaném kurikulu. Zajímalo nás proto, jakým způsobem ovlivňuje míra vnitřní koherence dokumentu celkové pojetí TV v Anglii.

Pojetí obsahů vzdělávacích dokumentů v daném státě je ovlivněno mnoha faktory. Patří mezi ně např historický vývoj vzdělávacího systému, jeho aktuální podoba, politicko-kulturní pozadí, geopolitická situace aj. Pro naši práci se jako zásadní jeví právě současný vzdělávací systém a historický vývoj vzdělávání a školní TV. Z hlediska kontextuality by proto bylo vhodné doplnit naši studii o patřičné deskripce zmíněných oblastí. Vhledem k omezenému rozsahu časopisecké studie jsme se však rozhodli zaměřit pouze na stručnou deskripci vzdělávacího systému v Anglii, již předkládáme níže. Zájemce o problematiku vývoje vzdělávání a TV v Anglii odkazujeme na relevantní

6 Uvědomujeme si však, že pouze z analýzy vzdělávacího oboru TV nemůžeme posuzovat kvalitu celého dokumentu. Stejně tak konstatujeme, že vzdělávací obor TV je součástí RVP ZV, a proto je jeho analyzování relevantní. 
autory (např. Seeley, 1904; Ignas et al., 1981; Kelly, 1987; Kirk, 1992; Fisher, 2005; Ježková et al., 2010; Hardman \& Parry, 2015 aj.).

Těžiště příspěvku leží v analýze kurikula TV v Anglii a jeho srovnání s podobou TV projektovanou v RVP ZV z hlediska zmíněných problémových témat, obsahu, formálních charakteristik a koncepce TV. Podle Naulova vektorového modelu (2011, s. 9) spadá koncepce TV v Anglii do směru reprezentujícího sportovní koncepci.

\section{Metodologie výzkumného šetření}

Jak jsme zmínili výše, použitá metodika byla částečně využita již v předchozích pracích; přesto se s každým dalším analyzovaným kurikulem TV vyvíjí. Na následujících řádcích proto stručně popíšeme podstatu použitých metod a hlavní změny, kterými výzkumný nástroj prošel.

V analýze vycházíme ze čtyřstupňového modelu srovnávání, který sestává z deskripce, interpretace, juxtapozice a vlastního srovnání (Bereday, 1966; Holmes, 1965, 1981; Manzon, 2007; Noah \& Eckstein, 1969). Tento model předpokládá předem formulovaný problém, který $\mathrm{v}$ našem př́́padě reprezentují zmíněná problémová témata vnitřní koherence a návodnosti. Protože se soustředíme na jeden vzdělávací dokument ${ }^{7}$, kombinujeme při jeho analýze problémový přístup a koncept př́ípadové studie. Sledovaným dokumentem je:

The national curriculum in England: Key stages 1 and 2 framework document (DfE, 2013). $V$ textu tento dokument (i jeho předchozí verze) pro přehlednost označujeme jako Národní kurikulum (NC).

Pro analýzu dokumentu jsme využili kategoriální systém (srov. Lupač, 2017), který prochází neustálým vývojem. Úzce vymezené kategorie byly definovány na základě vzdělávacího obsahu TV v RVP ZV (2017) s cílem dosažení maximální možné míry srovnatelnosti z české perspektivy. Kategorie jsou v rámci systému sjednoceny do pěti témat:

Webové stránky ministerstva školství nabízí ještě jeden dokument, a sice National Curriculum: Physical Education, Analysis of Progression Across the Key Stages (Department for Education, 2013), který by se dal považovat za standardy. Jak se ale při jeho analyzování ukázalo, obsahově dokument kopíruje to, co je již uvedeno v Národním kurikulu. Obsah Národního kurikula je v něm pouze přepsán do tabulky. Z toho důvodu nebyl tento dokument do analýzy zařazen. 
- problematika pohybových dovedností;

- problematika pohybových schopností;

- problematika vědomostí;

- problematika postojů;

- problematika jednání.

V souladu s tímto vymezením témat strukturujeme i část výsledků práce. Při zjištování vnitřní koherence sledujeme paralelu ke struktuře RVP ZV (2017) , návodnost a obsahovou dimenzi dokumentu porovnáváme na základě výše zmíněných témat. Zjištěné obsahové rozdíly, podobnosti a shody uvádíme ve výsledcích v částí 3.3 (Komparace NC s RVP ZV). Odtud plyne i naše první výzkumná otázka:

VO 1: Jaké jsou obsahové rozdíly, podobnosti a shody NC s RVP ZV?

Hledání dosažené míry vnitřní koherence ani návodnosti si neklademe za cíl vyjádřit v číslech, ale v porovnání s českým RVP ZV (Janík, Knecht, \& Kubiatko, 2011, s. 41), z čehož vyplývají i naše další dvě výzkumné otázky:

VO 2: Je více vnitřně koherentní anglické, nebo české kurikulum TV?

VO 3: Je více návodné anglické, nebo české kurikulum TV?

Výše popsané srovnání obsahové dimenze doplňujeme též deskripcí formálních charakteristik. Těmi jsou:

- formát;

- grafika;

- začlenění v rámci širšího kurikula;

- struktura;

- rozsah.

Odtud plyne i formulace další výzkumné otázky:

VO 4: Jaké jsou formální rozdíly, podobnosti a shody NC a RVP ZV?

Pro úplnost dodejme, že ačkoliv u RVP ZV uvádíme rok 2017, tento dokument vznikl již v roce 2004. Od té doby prošel řadou úprav, které však kromě přidání dvou očekávaných výstupů zaměřených na plavání neměly na podobu dokumentu v rámci vzdělávacího oboru TV žádný vliv. 
Poslední výzkumná otázka je věnována ověření Naulova diagramu (2011, s. 9):

VO 5: Jaká je koncepce TV v kurikulárních dokumentech Anglie?

Patrně nejzásadnější změnou v použité metodologii bylo zavržení systému témat, která jsme využili v analýze nizozemského kurikula (Lupač, 2016), a to pro jejich nekonzistentnost a problematickou hierarchii ${ }^{9}$, a jejich nahrazení novými tématy, která jmenujeme i v této části textu (tento nový výzkumný nástroj jsme využili i v předchozí práci, srov. Lupač, 2018).

\section{Výsledky}

Dříve než přikročíme k samotné analýze kurikulárního dokumentu TV, uvedeme avizovanou stručnou deskripci anglického vzdělávacího systému.

Informace pro tuto část byly čerpány $\mathrm{z}$ webových stránek anglického Ministerstva školství (Department for Education) ${ }^{10}$, dále $\mathrm{z}$ publikace Organisation of the education system in the United Kingdom - England, Wales and Northern Ireland (Eurybase, 2010) a rovněž z evropského portálu Eurydice. Neméně významným výchozím informačním zdrojem se stala publikace Školní vzdělávání ve Velké Británii (Ježková et al., 2010), a to mj. z důvodu terminologického uchopení překládaných pojmů, a Physical Education in England (Hardman \& Parry, 2015). Protože se v anglickém vzdělávacím systému i kurikulu vyskytují některé termíny, jejichž význam bychom z hlediska v Česku etablované pedagogické i kinantropologické terminologie mohli prostým překladem zkreslit, doplňujeme jejich překlad o originální znění v závorkách (vždy pouze při prvním výskytu).

\subsection{Vzdělávací systém Anglie se zaměřením na úroveň ISCED 1}

Současný britský vzdělávací systém je v porovnání s kontinentální Evropou poznamenán svým specifickým vývojem. Významným prvkem je dualita soukromého a státního školství (viz níže), která vznikla následkem absence státem řízeného školství v 19. století. V současnosti navštěvuje soukromé školy

\footnotetext{
Velmi problematicky bylo vnímáno např. uvedení problematiky zdraví a problematiky fyzické zdatnosti na stejné úrovni. Nevedou činnosti vedoucí ke zvýšení fyzické zdatnosti rovněž $\mathrm{k}$ podpoře zdraví? Docházelo tak k častému překryvu, který by měl být v kategoriálním (potažmo tematickém) systému ideálně nulový (srov. např. Hendl, 2005).

10 https://www.gov.uk/government/organisations/department-for-education
} 
přibližně $7 \%$ žáků v rámci povinné školní docházky, avšak ve věku 16 let je to již 18 \%. Přibližně 50 \% studentů elitních škol Oxfordu a Cambridge přitom běžně přichází právě ze soukromých škol. Velký rozdíl mezi kvalitou a výsledky soukromých a státních škol proto přetrvává navzdory snahám britských úřadů o jeho eliminaci (Ježková et al., 2010, s. 43).

Druhou významnou charakteristikou je dualismus náboženských a sekulárních škol. V r. 2007 mělo náboženský charakter přibližně 30 \% státních škol a 40 \% soukromých škol, školství v Anglii je rovněž poznamenáno výrazným multikulturalismem (srov. ONS, 2012).

S reformou školství v 80. letech minulého století a vznikem Národního kurikula $(1988)^{11}$ byl zaveden systém tzv. klíčových období (key stages) definovaných „nejen věkem žáků, ale i znalostmi a dovednostmi, které si žák má v jejich průběhu osvojit a jejichž zvládnutí bude na konci klíčových období zevrubně testováno" (Ježková et al., 2010, s. 46).

V Anglii, Walesu a Skotsku je povinná (a bezplatná) školní docházka určena dětem ve věku 5-16 let. ${ }^{12}$ Preprimární vzdělávání (ISCED 0) je pro děti ve věku 3-5 let a v Národním kurikulu nemá vymezeno žádné klíčové období. Primární vzdělávání (ISCED 1) zahrnuje děti ve věku 5-7 let a 7-11 let, tedy děti v prvním a druhém klíčovém období. Třetí klíčové období poskytuje dětem ve věku 11-14 let nižší sekundární všeobecné vzdělání (ISCED 2). Čtvrté klíčové období (věk 15-16 let) pokrývá spolu s neoficiálním pátým klíčovým obdobím, které představuje vyšší střední školu či alternativně instituce odborného vzdělávání, vyšší sekundární vzdělávání (ISCED 3).

Jak vyplývá z výkladového slovníku (Wallace, 2015), státní (veřejné) školy jsou v anglické odborné literatuře označovány jako state schools nebo (častěji) maintained schools, soukromé školy jsou označovány jako private schools, independent schools nebo public schools. Je proto nutné poznamenat, že termín public school má v Británii zásadně jiný význam, než jaký bychom mu mohli na základě běžného překladu (doslova „veřejné školy“) přisuzovat, nebot' označuje školy soukromé (Wallace, 2015, s. 243). Soukromé školy nejsou

11 Jednalo se o vůbec první kurikulum, které v Anglii vzniklo.

12 Ježková a kol. (2010, s. 46) uvádějí, že v roce 2013 má (resp. mělo) podle zákonné úpravy z roku 2008 dojít k navýšení věku pro horní hranici povinné školní docházky na 17 let a v roce 2015 na 18 let. Podle webových stránek Ministerstva školství je však věk povinné školní docházky doposud vymezen na 5-16 let (cit. 30. 11. 2018). Jak však ukážeme níže, alespoň částečně se musí žáci vzdělávat až do 18/19 let. 
finančně podporovány státem a nemusí se na rozdíl od většiny státních škol ř́idit NC.

Nejběžnější typy škol popisuje oficiální vládní portál GOV.UK (2018), který v rámci veřejného sektoru rozlišuje:

- Obecní školy (community schools) - jsou kontrolovány místními samosprávami, bez vlivu soukromých subjektů a církví.

- Nadační a dobrovolné školy (foundation schools a voluntary schools) mají větší svobodu ve způsobu vzdělávání než obecní školy.

- Akademie (academies) - státem financované školy nezávislé na místních samosprávách - nemusejí se řídit NC, většina z nich jsou školy sekundárního vzdělávání.

- Gymnázia (grammar schools) - výběrové školy, které většinu nebo všechny žáky vybírají na základě jejich akademických schopností. Velmi často je vyžadována přijímací zkouška.

- Speciální školy (special schools) - jsou určeny dětem starším 11 let a zaměřují se na jednu z následujících oblastí: komunikace a interakce; kognice a učení; sociální, emoční a psychické zdraví; senzorické a tělesné potřeby.

Vedle uvedeného rozdělení státních škol nabízí vládní portál i další dělení:

- náboženské školy (faith schools);

- bezplatné školy (free schools);

- městské průmyslové školy (city technology colleges);

- státní internátní školy (state boarding schools).

- soukromé školy (private schools).

Typy škol nejsou výlučné a mohou se různě kombinovat (existují soukromé speciální školy atp.), proto je poměrně obtížné organizaci škol v Anglii popsat. Na následujících řádcích se jí proto budeme věnovat z pohledu věku žáků.

Nejčastějším označením institucí poskytujících vzdělání dětem, které dosáhly věku tří let, je mateřská škola (nursery school). Předškolní vzdělání je ve většině Spojeného království poskytováno dětem do pěti let, avšak 
metodická a studijní literatura pro učitele často pokrývá věkové období 3-7 let, což zdůrazňuje kontinuitu edukačního působení mezi preprimárním a primárním vzděláváním. Ta je ukotvena též v organizační praxi, nebot' druhý ročník preprimárního vzdělávání (reception class) je součástí tzv. první části primárního vzdělávání (infant school nebo first school). Naproti tomu se nejnovější pojetí snaží prosadit jednotnou výchovu rovněž pro děti ve věku 0-5 let. $\mathrm{V}$ Británii je tento věk označován novým termínem zakládající období mladšího dětství (Early Years Foundation Stage, EYFS), se kterým pracuje i ministerstvo školství. Od r. 2000 se pro preprimární vzdělávání objevují rámcové dokumenty, jejichž poslední verze pochází z r. 2017.13 První stupeň základní školy (primary school) navštěvují děti ve věku 5-11 let a z hlediska Národního kurikula je vymezen prvním a druhým klíčovým obdobím. Původní základní škola (elementary school) byla na primární a sekundární školu rozdělena definitivně až v r. 1944 Butlerovým zákonem, avšak úvahy o charakteru vzdělávání na primárním stupni můžeme nalézt již ve dvacátých letech 20. století. Pojetí primárního vzdělávání bylo směřováno v duchu progresivní reformní výchovy a při vyučování kladlo „do popředí procesy a méně se soustřed'ovalo na poznatky“ (Ježková et al., 2010, s. 53). V intencích tohoto pojetí se charakter primárního stupně formoval i nadále ještě v šedesátých letech se dbalo na to, aby se žák vyvíjel vlastním tempem prostřednictvím individuálního objevování a vlastních bezprostředních zkušeností, též se upouštělo od frontální výuky. Způsob vzdělávání, ve kterém bylo dítě postaveno do centra zájmu, však byl dle některých kritiků důvodem významného zhoršení výkonu žáků. Současné snahy ve vzdělávání v rámci primární školy usilují o zajištění vysoké efektivity a kvality vzdělávání pro všechny žáky při zachování radosti z objevování, neméně významné je rovněž téma vyváženosti hloubky a šíře kurikula.

Sekundární vzdělávání zahrnuje třetí a čtvrté klíčové období a absolvují jej žáci ve věku 11-16 let. Žáci jej mohou absolvovat na třech typech škol (tripartitní systém sekundárních škol): gymnaziální školy (grammar school), nižší technické školy (junior technical school) a moderní sekundární školy (praktická orientace, secondary modern school). V praxi vzniklo velmi málo technických škol - většina úřadů integrovala dva typy škol nebo vytvářela jednotné školy (komprehenzivní školy, comprehensive school), které v současnosti navštěvuje přibližně $90 \%$ žáků.

13 Statutory framework for the early years foundation stage: Setting the standards for learning, development and care for children from birth to five (DfE, 2017). 
Ačkoliv se jako věk pro povinnou školní docházku uvádí 5-16 let, žáci ve věku 16-18/19 let musejí navštěvovat prezenční nebo kombinované vzdělávání či praktickou př́pravu (full-time nebo part-time education, training). Toho dosahují prostřednictvím všeobecně zaměřeného studia v rámci vyššího sekundárního vzdělávání, tzv. sixth form, jež nabízí většina sekundárních škol a které se rovněž neoficiálně označuje jako páté klíčové období (Eurydice, 2018).

Vysokoškolské vzdělání (higher education) studenti získávají na univerzitách. Studium sestává z obvykle tř́letého undergraduate course, na jehož konci studenti získají bakalářský titul (Bachelor's degree). Nejvyšší formou je postgraduate course, jehož výstupem je magisterský (Master's degree), př́íp. doktorský titul (Doctor of Philosophy, Ph.D.).

Jak z uvedené deskripce vyplývá, organizace škol v Anglii je značně rozmanitá a i přes některé podobnosti se celkově českému systému př́liš nepodobá. Současný stav patrně nastal v důsledku vývoje, jehož nejdůležitějšími mezníky byly pozdní převzetí odpovědnosti za vzdělávání státem $\mathrm{v}$ druhé polovině 19. století ${ }^{14}$ a reforma školství v 80 . letech minulého století, která v Anglii započala překotný vývoj, jenž dodnes neskončil (srov. Dvořák, Holec, \& Dvořáková, 2018).

\subsection{Analýza kurikula TV}

První verzi NC vydalo ministerstvo školství roku 1988 (s účinností od roku 1989), avšak TV se v něm poprvé objevila až po úpravě z roku 1992 (Hardman \& Parry, 2015, s. 157). Současná verze dokumentu z roku 2013 je oficiálně pouze elektronická, nicméně nakladatelství Scholastic dokument vydalo pod názvem The National Curriculum in England, Key Stages 1 \& 2: Handbook for Primary Teachers rovněž jako knihu v měkkých deskách se zachováním obsahu, avšak pozměněním některých formálních charakteristik. $\mathrm{V}$ přehledové tabulce $1 \mathrm{v}$ kapitole 3.3 (Komparace $N C s$ RVP ZV) proto zmiňujeme elektronickou i tištěnou verzi a poukazujeme na jejich formální odlišnosti. Pro deskripci formálních charakteristik, kterou uvádíme na následujících řádcích, jsme využili oficiální elektronickou verzi.

14 Povinná školní docházka byla v Anglii zavedena v roce 1880, přesto stát až do 70 . let 20. století zasahoval do vedení škol a jejich kurikula velmi málo. 
Formální charakteristiky analyzovaného dokumentu

Sledovaný dokument má celkem 201 stran. NC kombinuje černou a modrou barvu, kterými zpřehledňuje nadpisy a tabulky. Dokument neobsahuje žádné obrázky.

Z hlediska struktury je NC rozděleno do několika kapitol. Jsou jimi:

- Obsah - 2 strany;

- Úvod - 1 strana;

- Školní kurikulum v Anglii (obdoba českého ŠVP) - 1 strana;

- Národní kurikulum v Anglii - zahrnuje obecné vzdělávací cíle a strukturu anglického kurikula včetně distribuce předmětů v jednotlivých věkových skupinách, 2 strany;

- Inkluze - 1 strana;

- Počítání a matematika - 1 strana;

- Jazyk a jazyková gramotnost (Language and literacy) - 1 strana;

- Vzdělávací obory a očekávané výstupy (Programmes of study and attainment target) - 189 stran.

Jednotlivým vzdělávacím oborům je v dokumentu věnováno různé množství textu. Největší důraz je kladen na anglický jazyk (85 stran), matematiku (45 stran) a př́rodní vědy (Science, 32 stran). Ostatním oborům jsou věnovány 2-4 strany.

TV zaujímá $\mathrm{v}$ dokumentu 3 strany a je $\mathrm{v}$ něm zařazena na poslední místo. Z hlediska struktury se nijak neliší od ostatních předmětů. Po krátkém odstavci, který odůvodňuje zařazení TV do kurikula (Purpose of study), následují čtyři cíle TV (Aims), které jsou vymezeny v odrážkách. Za nimi je zařazen očekávaný výstup a vzdělávací obsah (Subject content), který je definován pro každou klíčovou úroveň zvlášt'. V něm se nachází krátká charakteristika pokroku, kterého by žáci měli na dané úrovni dosáhnout. Protože se v této charakteristice často objevuje syntaktická vazba „Žáci by měli [...]“ nebo „Žáci by měli být schopni [...]" (Pupils should nebo Pupils should be able), tuto část můžeme z české perspektivy označit za očekávané výstupy. Následuje výčet činností, kterým by měli být žáci vyučováni (Pupils should be tought to...). Z toho důvodu můžeme dokument označit jako content based curriculum. Mimo 
vzdělávací obsah definovaný pro obě klíčové úrovně je vymezeno plavání, jehož výuku škola může poskytnout bud' na první, nebo druhé klíčové úrovni.

Poznamenejme, že výše naznačená struktura vzdělávacího oboru je v NC společná všem vzdělávacím oborům vyjma angličtiny, matematiky a př́rodních věd.

\section{Obsahová dimenze analyzovaného dokumentu}

Stejně jako všechny ostatní vzdělávací obory má i kapitola věnující se TV v NC jasnou strukturu. Krátký úvodní odstavec se věnuje významu TV v anglickém kurikulu. Uvádí, že:

Vysoce kvalitní kurikulum TV inspiruje žáky, aby uspěli a vynikali ve výkonnostních sportech (competitive sport) a dalších fyzicky náročných aktivitách. Mělo by žákủm poskytnout př́ležitosti $\mathrm{k}$ tomu, aby byli pevně přesvědčeni o benefitech pohybové aktivity (physically confident) pro zdraví a zdatnost. Př́ležitosti ke sportování a dalším aktivitám budují charakter a pomáhají ukotvit hodnoty jako férovost a respekt (DfE, 2013, s. 198).

Část Cíle není doplněna doprovodným textem jako $\mathrm{v}$ některých jiných dokumentech (např. RVP ZV nebo švédské projektované kurikulum ${ }^{15}$ ). Z cílů je patrné zaměření TV na vysokou kvalitu zvládání pohybu, soutěživost a snahu udržet vysokou úroveň pohybové aktivity žáků i mimo školu. Jejich přehled nabízíme v tabulce 2 , ve které je stavíme do juxtapozice se vzdělávacími cíli RVP ZV.

V části o TV dále NC předkládá jediný, poměrně vágně formulovaný očekávaný výstup (Attainment targets), který se opakuje ve všech vzdělávacích oborech, a proto jej můžeme vztáhnout na celý vzdělávací obsah v NC. Ve výstupu je uvedeno, že „se od žáků na konci každé klíčové úrovně očekává, že budou rozumět obsahům, dovednostem a procesům specifikovaným $\mathrm{v}$ př́íslušném vzdělávacím oboru a zároveň je uplatňovat“16 (DfE, 2013, s. 198).

15 Curriculum for the compulsory school, preschool class and the leisure-time centre 2011 (2011, s. 50).

16 „By the end of each key stage, pupils are expected to know, apply and understand the matters, skills and processes specified in the relevant programme of study." (DfE, 2013, s. 198). 
Část věnovaná vzdělávacímu obsahu je rozdělena na klíčové úrovně 1 a 2 . Každou úroveň uvádí krátký odstavec, který svým charakterem připomíná očekávané výstupy, které jsou však formulovány v podmiňovacím způsobu ${ }^{17}$ a které svým obsahem cílům ve značné míre neodpovídají (viz výsledky). Vzdělávací obsah (a rovněž další relevantní části dokumentu) rozebíráme na následujících řádcích $\mathrm{z}$ hlediska témat, která uvádíme v použité metodologii.

\section{Problematika dovedností}

Dokument uvádí, že na první klíčové úrovni by žáci měli rozvinout základní pohybové dovednosti. V samotném učivu jmenuje konkrétně běhání, skákání, házení a chytání. Dále by měli být schopni v tanci využívat jednoduché pohybové prvky (movement patterns).

V rámci druhé klíčové úrovně by žáci zmíněné základní pohybové dovednosti měli rozšiřovat a rozvíjet a měli by být schopni je používat izolovaně i v různých kombinacích. Přidává se rozvoj různých technik. $\mathrm{V}$ tanci by žáci měli rozšírit zásobu pohybových prvků.

V plavání by žáci měli být schopni efektivně používat některé plavecké styly (nezávazně je doporučen kraul, znak a prsa).

\section{Problematika pohybových schopností}

Na první klíčové úrovni anglický dokument v učivu uvádí, že by žáci měli mít př́ležitost ke zlepšování hbitosti, koordinace a rovnováhy, at’ už individuálně nebo společně s dalšími žáky. Spolu s výše uvedenými dovednostmi by tyto schopnosti měli začít uplatňovat v širokém okruhu aktivit.

Ačkoliv se v charakteristice druhé klíčové úrovně již o pohybových schopnostech nehovoří, jsou zahrnuty v jejím učivu. Žáci by tak nadále měli být vedeni k rozvoji ohebnosti, síly, kontroly a rovnováhy (nezávazně je doporučeno rozvíjet tyto schopnosti prostřednictvím atletiky a gymnastiky).

\section{Problematika vědomostí}

Vědomosti jsou v první klíčové úrovni obsaženy spíše v menší míre. Vztahují se převážně ke kooperaci a rozvoji jednoduchých obranných a útočných taktik.

17 „Žáci by měli...” 
V druhé klíčové úrovni jsou vědomosti využity především na zefektivnění dovedností. Dokument uvádí, že žáci by se měli učit, jak naučené dovednosti využívat různými způsoby a propojovat je do různých akcí nebo sekvencí pohybů. Měli by též rozvíjet porozumění tomu, jak se zlepšit v různých pohybových aktivitách a sportech (physical activities and sports) a jak vyhodnocovat a rozpoznávat svůj vlastní úspěch. Měli by umět srovnat své aktuální výkony s těmi předchozími. Žáci by na druhé klíčové úrovni měli být vyučováni soutěžním sportovním hrám ${ }^{18}$ (competitive games) modifikovaným tam, kde je to vhodné, což implikuje znalost jejich pravidel (nezávazně je doporučen badminton, košíková, kriket, fotbal, pozemní hokej, netball, rounders ${ }^{19}$ a tenis). Stejným způsobem jsou implicitně obsaženy vědomosti o bezpečnosti ve vodě (water safety), když dokument uvádí, že žáci by měli umět předvést bezpečnou sebezáchranu v různých situacích, do kterých se mohou ve/na vodě dostat (water-based situations).

\section{Problematika postojů}

Postojová složka je v anglickém kurikulu TV velmi silně zastoupena. Již v charakteristice vzdělávacího oboru je implicitně zahrnut kladný postoj k výkonnostnímu sportu a pohybovým výzvám. Explicitně je dále uvedeno přesvědčení o benefitech pohybu pro zdraví a zdatnost.

Postoje se promítají rovněž do cílů kurikula. Zaměřeny jsou mj. na kladný postoj k celoživotní pohybové aktivitě.

Již méně se o postojích hovoří v učivu. Implicitně můžeme vyčíst snahu tvůrců kurikula o rozvoj jisté odvahy, která je zmíněna na první klíčové úrovní v podobě zapojování žáků do soutěžních i kooperativních aktivit, které pro ně mají být zvyšující se výzvou. Jasněji se o postojích hovoří až na druhé klíčové úrovni, kde se uvádí, že by se žáci měli bavit komunikací, spoluprací a soutěžením s ostatními.

18 Evropská charta sportu uvádí, že sportem se rozumí „všechny formy tělesné činnosti, které, at' již prostřednictvím organizované účasti či nikoli, si kladou za cíl projevení či zdokonalení tělesné i psychické kondice, rozvoj společenských vztahů nebo dosažení výsledků v soutěžích na všech úrovních" (Rada Evropy, 1992, s. 2). Z toho důvodu si dovolujeme na tomto místě upřesnit pojem sport adjektivem soutěžní, nebot' dle jiných definic by tak měl být sport chápán pokaždé.

19 Netball je obdoba korfbalu, rounders je pálkovací hra podobající se softballu nebo baseballu. 


\section{Problematika jednání}

Konativní složka kurikula je v úzkém propojení s postoji, které by si měl žák během školní docházky osvojit. $V$ anglickém kurikulu je zahrnuta především ve dvou cílech: vedení zdravého a aktivního života a zapojování do výkonnostních sportů a aktivit. Učivo pak tyto konativní cíle naplňuje - nejsou definovány jako nějaký obsah, se kterým může učitel libovolně zacházet, ale formulace zní: „Žáci by měli být vyučováni: ... (DeF, 2013)“, a následuje za ní plnovýznamové sloveso, které odkazuje na to, že teprve určitou činností dojde k naplnění konkrétních cílů. Zmíněny jsou základní hodnoty jako férovost a respekt, které mohou ovlivňovat a utvářet jednání žáků.

Přiřazení anglického kurikula $\mathrm{k}$ jedné z koncepcí TV, jak je definuje Naul (2011, s. 9), není vzhledem ke snížené vnitřní koherenci vnitřních částí dokumentu jednoznačné. Charakteristika vzdělávacího oboru umist'uje dokument na pomezí sportovní a zdravotní koncepce TV s př́íklonem ke sportovní koncepci. Čtyři vzdělávací cíle jsou rovnoměrně rozloženy mezi sportovní a zdravotní koncepci a učivo spadá jasně do sportovní koncepce. Proto můžeme celkovou koncepci TV v NC označit spíše za sportovní.

\subsection{Komparace NC s RVP ZV}

V samotném srovnání anglického kurikula TV s českým se nejprve zaměříme na formální charakteristiky a poté se budeme věnovat obsahové dimenzi.

Formální charakteristiky přehledně shrnujeme níže (tabulka 1). 


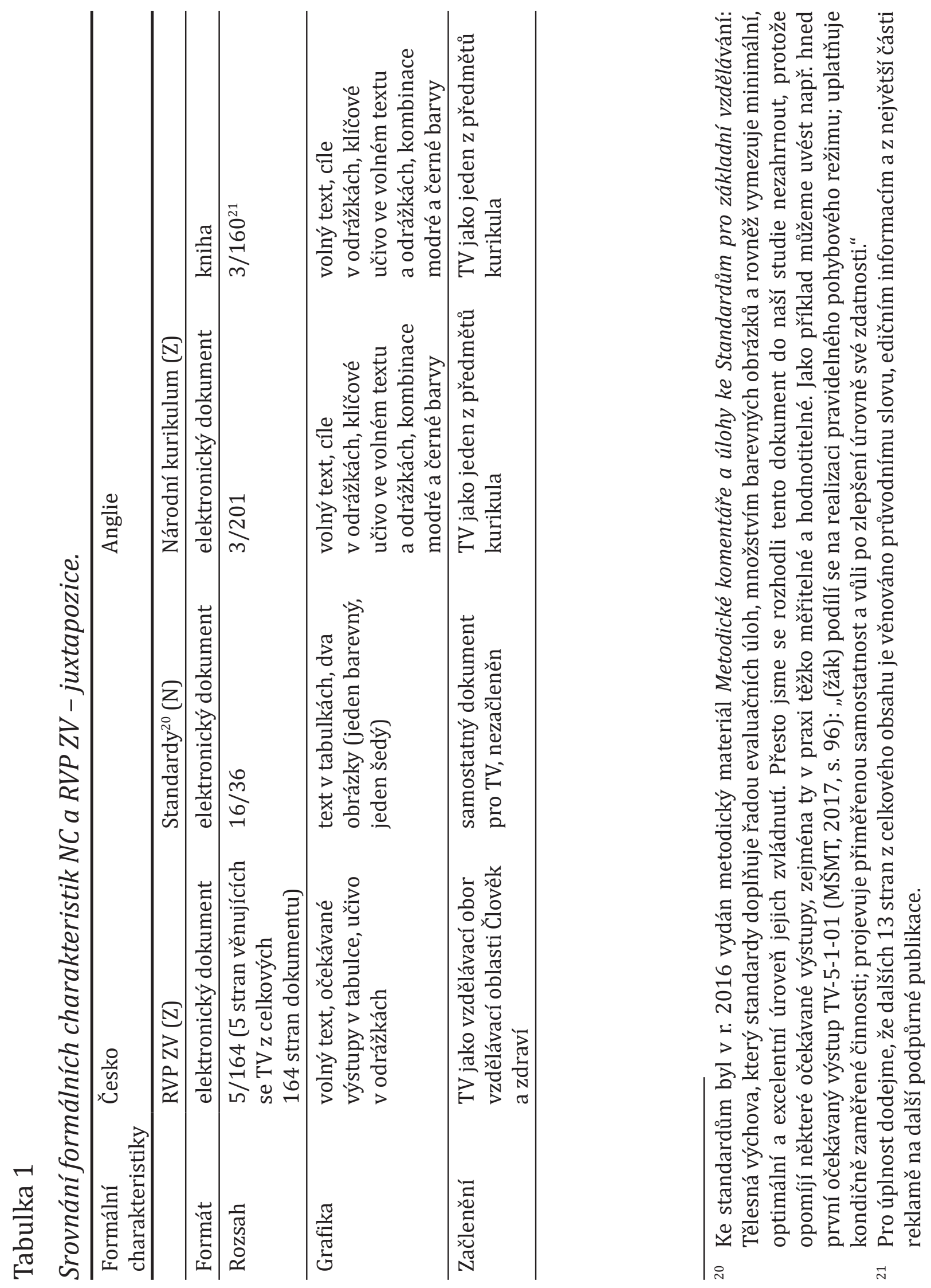




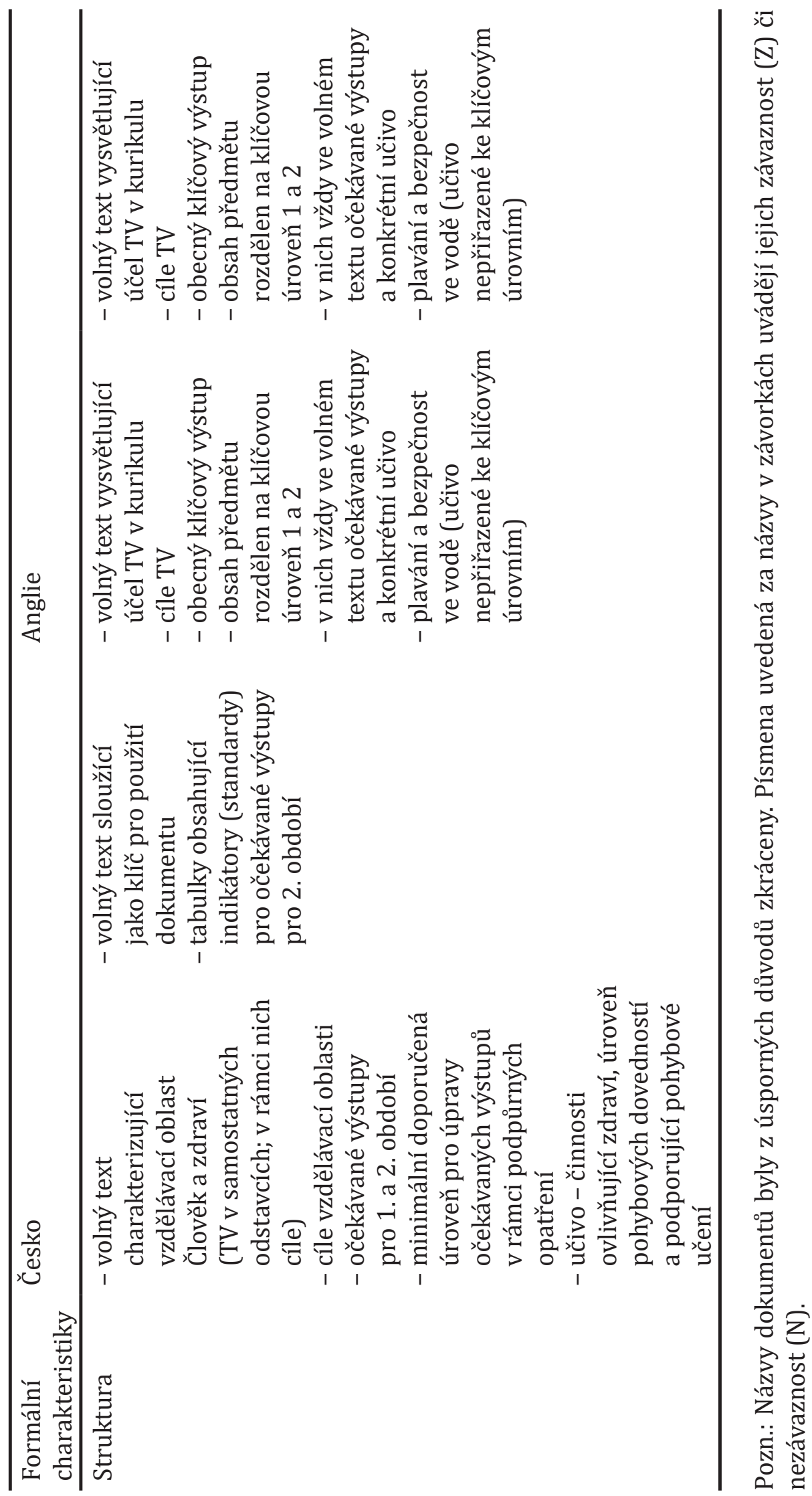


Z hlediska formálních charakteristik můžeme říci, že dokumenty jsou vzájemně srovnatelné - RVP ZV i NC disponuje společnou charakteristikou vzdělávacího oboru pro 1. a 2. vzdělávací období (obdobně klíčové úrovně 1 a 2 v NC). Zatímco RVP ZV má učivo společné pro obě vzdělávací období a rozděleny jsou jen očekávané výstupy, anglické kurikulum uvádí očekávané výstupy i učivo rozdělené na 1. a 2. klíčovou úroveň. Významným rozdílem je faktická absence standardů v systému anglického kurikula, které český systém kurikulárních dokumentů nabízí nezávazně mimo RVP ZV. Podívámeli se tak na celkový rozsah dokumentů, zjistíme, že české kurikulum TV je obsáhlejší než anglické. To je dáno společnou charakteristikou vzdělávacích oborů TV a Výchova ke zdraví (VkZ) v rámci vzdělávací oblasti Člověk a zdraví a větším množstvím očekávaných výstupů a učiva (které je v RVP ZV pouze doporučeno).

Půjdeme-li v dokumentech o úroveň výš, zjistíme, že TV je v NC vymezena jako samostatný vzdělávací obor se svými cíli a očekávanými výstupy, zatímco TV v českém kurikulu spadá do vzdělávací oblasti Člověk a zdraví. VkZ není oproti RVP ZV v NC věnována samostatná část, avšak problematika zdraví se dílčím způsobem objevuje v cílech TV.

Z hlediska struktury je české i anglické kurikulum jasně členěno. Zatímco učivo v NC je strukturováno pouze podle věku žáků na klíčové úrovně, v RVP ZV se objevuje i další členění, konkrétně na Činnosti ovlivňující zdraví, Činnosti ovlivňující úroveň pohybových dovedností a Činnosti podporující pohybové učení. ${ }^{22}$ Mírně problematicky vnímáme lehce duplicitní uvedení cílů TV v RVP ZV, které jsou implicitně rozvedeny v charakteristice vzdělávací oblasti, dále jsou shrnuty do podoby Cílového zaměření vzdělávací oblasti (tedy nikoliv pouze TV) a opětovně rozpracovávány do očekávaných výstupư ${ }^{23}$.

NC i RVP ZV shodně uvádějí rozvoj základních pohybových dovedností jako běhání, skákání, házení a chytání, avšak RVP ZV je dává do souvislosti

22 Činnosti ovlivňující zdraví postihují to nejpodstatnější, co TV vzhledem k podpoře zdraví nabízí, učivo v Činnostech ovlivňujících úroveň pohybových dovedností směřuje k rozvoji těch pohybových dovedností, které u žáků zajišt’ují oblibu TV a jejich socializaci, a Činnosti podporující pohybové učení jsou zaměřeny na podpůrné činnosti.

23 Ty jsou sice rozpracovány odděleně pro TV a VkZ, avšak VkZ je v RVP ZV definována jen pro druhý stupeň (problematice zdraví se na úrovni 1. stupně věnuje vzdělávací obor stejnojmenné vzdělávací oblasti Člověk a jeho svět v části Člověk a jeho zdraví, avšak převážně v rámci oblastí života, které nejsou spojeny s aktivním pohybem, viz MŠMT, 2017, s. 49-50). 
s atletikou, zatímco NC je (spolu s pohybovými schopnostmi) vnímá jako základní předpoklad ke zvládání dalších pohybových činností - jejich zvládnutí je tak chápáno více jako prostředek než samotný cíl. NC uvádí konkrétní sportovní hry a klade důraz na kooperaci, útočné a obranné taktiky, RVP ZV místo toho $v$ rámci sportovních her uvádí dovednosti, které je potřeba obecně zvládnout, jako je manipulace s míčem, pálkou či jiným náčiním atp. V rámci dovedností navíc uvádí průpravné úpoly, bruslení a lyžování. Oba dokumenty předepisují tanec a plavání.

Pohybové schopnosti, které NC doporučuje rozvíjet prostřednictvím atletiky a gymnastiky, české kurikulum uvádí v Činnostech ovlivňujících zdraví. NC i RVP ZV zmiňují jejich využití nejen v individuálních činnostech, ale také společně s ostatními žáky, a zdůrazňují tak kooperativní zaměření vzdělávacího obsahu ${ }^{24}$ i smysl rozvoje schopností teprve až při jejich využití v dalších pohybových činnostech (viz výše).

Vědomosti jsou ve vzdělávacím obsahu českého i anglického kurikula obsaženy převážně implicitně jako předpoklad pro zvládnutí určitých dovedností. Avšak zatímco v NC hrají důležitou roli především znalosti pravidel různých sportovních a týmových her (i modifikovaných) a dále jim v dokumentu není věnována př́lišná pozornost, RVP ZV je uvádí rovněž na jiných místech. V části Činnosti ovlivňující zdraví jsou zahrnuty v podobě znalostí z hygieny při TV, prevence a péče o zdraví. Vědomosti jsou hojně zastoupeny i v části Činnosti podporující pohybové učení, ve které se hovoří o komunikaci v TV, organizaci při TV nebo měření a posuzování pohybových dovedností (což je však obsaženo i v NC v rámci posuzování vlastního výkonu). V obou dokumentech jsou zahrnuty vědomosti týkající se bezpečnosti na/ve vodě.

Postojová složka zaujímá pevné místo v obou srovnávaných dokumentech, avšak liší se ve svém zaměření. NC zmiňuje kladný postoj k výkonnostnímu sportu a pohybovým výzvám, který se prolíná všemi částmi dokumentu. RVP ZV zdůrazňuje především kladný postoj ke zdraví, který je ukotven hlavně $\mathrm{v}$ cílech, mnohem méně pak $\mathrm{v}$ očekávaných výstupech a učivu. ${ }^{25} \mathrm{NC}$ př́mo uvádí přesvědčení o benefitech pohybové aktivity pro zdraví a zdatnost.

${ }^{24}$ Ačkoli je v obou dokumentech zmíněno v očekávaných výstupech pro 1. období (resp. v NC v učivu pro 1. klíčové období) a později již ne.

25 V sedmi z devíti vzdělávacích cílů se hovoří o zdraví, avšak ze dvanácti očekávaných výstupů pro 2. vzdělávací období jsou pouze tři zaměřeny na problematiku zdraví. 
Výrazným prvkem v NC je implicitní snaha o rozvoj jisté odvahy prostřednictvím zvyšujících se výzev a soutěžení a s tím související snaha o to, aby se žáci pohybem bavili. V RVP ZV je v jednom z cílů explicitně uvedeno, že vzdělávání v TV vede žáky „k vnímání radostných prožitků z činností podpořených pohybem" (MŠMT, 2017, s. 92) a v očekávaných výstupech i učivu je soutěžení zmíněno, avšak soutěživost jako postojová složka není v dokumentu nijak explicitně zdůrazňována.

Z hlediska konativní složky kurikula oba sledované dokumenty zmiňují férovost jako základní hodnotu (NC již v úvodu vzdělávacího oboru, RVP ZV v cílech a v učivu), RVP ZV navíc nabízí prostor pro rozvoj jednání v duchu olympijských ideálů a symbolů.

Cíle v NC vyváženě směřují dokument ke sportovní a zdravotní koncepci TV, cíle v českém dokumentu silně směřují ke zdravotní koncepci TV. Některé části RVP ZV, které se problematiky zdraví dotýkají, bychom navíc mohli rovněž zahrnout do vzdělávání $v$ oboru TV. Konkrétně se jedná o jeden z obecně vymezených cílů základního vzdělávání, kterým je „učit žáky aktivně rozvíjet a chránit fyzické, duševní a sociální zdraví a být za ně odpovědný" (MŠMT, 2017, s. 9) nebo některé očekávané výstupy ze vzdělávacího obsahu vzdělávacího oboru Člověk a jeho svět s podnázvem Člověk a jeho zdraví, např. očekávaný výstup ČJS-5-5-06 „,žák) uplatňuje základní dovednosti a návyky související s podporou zdraví a jeho preventivní ochranou" (MŠMT, 2017, s. 49). Vzdělávací cíle TV obou dokumentů přehledně shrnuje tabulka 2.

\section{Tabulka 2}

Přehled vzdělávacích cílu TV v českém a anglickém kurikulu

\begin{tabular}{ll}
\hline RVP ZV & Národní kurikulum \\
\hline $\begin{array}{l}\text { Vzdělávání v této vzdělávací oblasti směřuje k utváření a rozvíjení } \\
\text { klíčových kompetencílemáků tím, že vede žáky k: }\end{array}$ & $\begin{array}{l}\text { kurikulu je ujistit se, že } \\
\text { všichni žáci: }\end{array}$ \\
\hline $\begin{array}{l}\text { poznávání zdraví jako důležité hodnoty v kontextu dalších } \\
\text { životních hodnot }\end{array}$ & $\begin{array}{l}\text { rozvíjí kompetence } \\
\text { k excelentnímu zvládnutí } \\
\text { širokého spektra } \\
\text { pohybových aktivit }\end{array}$ \\
\hline $\begin{array}{l}\text { pochopení zdraví jako vyváženého stavu tělesné, duševní } \\
\text { i sociální pohody a k vnímání radostných prožitkủ z činností } \\
\text { podpořených pohybem, př́íjemným prostředím a atmosférou } \\
\text { příznivých vztahů }\end{array}$ & $\begin{array}{l}\text { jsou dlouhodobě } \\
\text { pohybove aktivní }\end{array}$ \\
\hline
\end{tabular}




\begin{tabular}{ll}
\hline RVP ZV & Národní kurikulum \\
\hline $\begin{array}{l}\text { poznávání člověka jako jedince závislého v jednotlivých etapách } \\
\text { života na způsobu vlastního jednání a rozhodování, na úrovni } \\
\text { mezilidských vztahů i na kvalitě prostředí }\end{array}$ & $\begin{array}{l}\text { se zapojují do } \\
\text { výkonnostních sportů } \\
\text { a aktivit }\end{array}$ \\
\hline $\begin{array}{l}\text { získávání základní orientace v názorech na to, co je zdravé a co } \\
\text { může zdraví prospět, i na to, co zdraví ohrožuje a poškozuje }\end{array}$ & $\begin{array}{l}\text { vedou zdravé, aktivní } \\
\text { životy }\end{array}$ \\
\hline $\begin{array}{l}\text { využívání osvojených preventivních postupů pro ovlivňování } \\
\text { zdraví v denním režimu, k upevňování způsobů rozhodování }\end{array}$ \\
$\begin{array}{l}\text { a jednání v souladu s aktivní podporou zdraví v každé životní } \\
\text { situaci i k poznávání a využívání míst souvisejících s preventivní } \\
\text { ochranou zdraví }\end{array}$ \\
\hline
\end{tabular}

propojování činností a jednání souvisejících se zdravím a zdravými mezilidskými vztahy, se základními etickými a morálními postoji, s volním úsilím atd.

chápání zdatnosti, dobrého fyzického vzhledu i duševní pohody jako významného předpokladu výběru profesní dráhy, partnerů, společenských činností atd.

ochraně zdraví a životů při každodenních rizikových situacích i mimořádných událostech a k využívání osvojených postupů spojených s řešením jednotlivých mimořádných událostí

aktivnímu zapojování do činností podporujících zdraví a do propagace zdravotně prospěšných činností ve škole i v obci

Zdroj: MŠMT (2017, s. 92) a DfE (2013, s. 198).

Vzájemné srovnání vnitřní koherence dokumentů vychází z koncepce TV, které jejich jednotlivé části prezentují. Linii charakteristika $=>$ vzdělávací cíle $=>$ učivo dodržuje NC jen částečně, nebot' předepsané učivo odpovídá čistě sportovní koncepci TV a nerozvíjí některé cíle ${ }^{26}$. Protože stejný nesoulad tíží i RVP ZV (srov. Lupač, 2016, s. 29), můžeme konstatovat, že jsou oba dokumenty z hlediska vnitřní koherence (nekoherence) srovnatelné. NC navíc postrádá měřitelné standardy, které by míru dosažení vzdělávacích cílů objektivně hodnotily.

Zaměříme-li se na druhý sledovaný faktor, kvalitu, můžeme konstatovat, že český systém dokumentů je návodnější než anglický. Český dokument obsahuje více učiva, které je (byt' v malé míře) hlouběji rozpracováno, a podobná je situace i v př́ípadě vzdělávacích cílů. Ty české kurikulum konkretizuje do

26 Jmenujme např. cíl „[...] žáci vedou zdravé, aktivní životy“ (DfE, 2013, s. 198), který je na hranici rozporu s výkonnostním a sportovním pojetím učiva, které v žádné své části př́mo podporu zdraví nerozvíjí. 
očekávaných výstupư ${ }^{27}$, jež jsou měřitelné pomocí standardů. NC též uvádí očekávané výstupy (ač je tak nepojmenovává), ale ty rozpracovávají jen některé cíle a jsou více spjaty s učivem. Pro úplnost dodejme, že české kurikulum je širší nejen $v$ rámci učiva, ale rovněž charakteristiky vzdělávacího oboru, cílů a standardů.

\subsection{Diskuze}

Dřívější práce autorů zahrnovaly studie kurikula TV v dalších evropských státech (Lupač, 2016, 2018), kde se objevují kurikula s pohybově a zdravotně pojatou TV. Odhlédneme-li od obsahových odlišností a zaměříme-li se na sledované faktory kvality, musíme konstatovat, že švédské a nizozemské kurikulum vykazuje vyšší míry návodnosti ( $\mathrm{v}$ případě Nizozemska) a vnitřní koherence (v případě Nizozemska i Švédska) než kurikulum v Anglii a České republice. Jedním z důvodů naznačeného stavu může být (ne)zkušenost s tvorbou kurikula, která byla v Anglii i České republice zapříčiněna některými politickými a historicko-kulturními faktory. $V$ Anglii je to především na evropské poměry krátký historický vývoj kurikulárních dokumentů a vůbec řízení celého školství na státní úrovni (až od r. 1988, resp. 70. let 20. stol.), v Česku pak dlouhý vliv komunistického režimu a v novém tisíciletí snaha o vytvoření revolučního kurikula, která však byla uspěchána (srov. Šíp, 2014; Tupý, 2018, aj.).

V úvodu práce se zmiňujeme o civilizačních chorobách, které Anglii sužují. Uvedli jsme, že jedním ze způsobů jejich řešení může být i vzdělávání budoucích generací v oblasti pohybu a s tím spojené pojetí realizace TV, které by mělo tíhnout ke zdravotně orientované koncepci. TV Současná tělesná výchova a školní sport (physical education and school sport) je prezentována jako předmět, ve kterém by se žáci měli celoživotně vzdělávat, který by je měl vybavit pohybovou gramotností a vychovat $\mathrm{z}$ nich pohybově vzdělané jedince. Zároveň by je měl připravit na boj proti nemocem způsobeným sedavým stylem života, proti antisociálnímu chování, zvyšující se úrovni obezity a inaktivity a zároveň produkovat „zástupy talentovaných lidí schopných uspět a získat medaile na mezinárodních kláních“ (Hardman \& Parry, 2015, s. 175). Současná podoba TV v anglickém kurikulu tak bezesporu souvisí s dlouhou sportovní tradicí spojenou s rủznými sportovními kluby a asociacemi, které se zasazovaly o zahrnutí TV do kurikula a které jeho podobu

27 Byt’ tato konkretizace v některých případech působí spíše jako duplicita. 
ovlivňovaly už v době, kdy stát nedržel vzdělávací (a kurikulární) politiku pevně ve svých rukou. Zároveň se však snaží reflektovat potřeby dnešní společnosti. Jak autoři dále uvádí, v současnosti prezentovaná koncepce je ideální variantou. Skutečností ale zůstává, že realizovaná forma kurikula TV stále vychází ze sportovní tradice, která se v Anglii etablovala v 19. století, ačkoliv (alespoň v cílech) prezentovaná koncepce se snaží odchýlit od sportovního pojetí spíše ke zdravotnímu. Současné projektované cíle TV totiž sice částečně směřují ke sportovní koncepci, ale jsou také značně postojové a ještě výrazněji směřují k celoživotní pohybové aktivitě coby fundamentální klíčové kompetenci (řečeno terminologií českých dokumentů), kterou by si žáci měli odnést do života.

\section{Závěr}

Předložená stat' se snaží zmapovat současný stav projektovaného kurikula TV v Anglii s přihlédnutím k problémovým tématům vnitřní koherence a návodnosti. Pro doplnění kontextu stručně popisuje anglický vzdělávací systém.

Ve výsledkové části analyzujeme NC z hlediska jeho obsahu i formální podoby a naše zjištění srovnáváme s českým RVP ZV. Z uvedených dat vyplývá, že anglické kurikulum je méně návodné a úroveň vnitřní koherence je obdobně problematická skrze koncepční nesoulad mezi některými částmi dokumentu, jako je tomu i v RVP ZV. V př́ípadě NC jsou v souladu očekávané výstupy a učivo (sportovní koncepce TV), avšak ty společně příliš neodpovídají cílům (vyvážená sportovní a zdravotní koncepce TV). V českém kurikulu spolu též korespondují očekávané výstupy a učivo (inklinace k pohybové koncepci TV), avšak společně zcela nekorespondují s cíli (silná tendence ke zdravotní koncepci TV). Zároveň je NC méně široké, nebot' nabízí užší okruh aktivit (absentují např. činnosti ovlivňující zdraví, úpoly, lyžování nebo bruslení), a o něco méně hluboké.

Naše studie navazuje na dřívější práce autora (Lupač, 2016, 2018), ve kterých se pokoušíme analyzovat kurikulární dokumenty TV ve vybraných evropských státech s cílem nalézt v nich inspiraci pro probíhající revize RVP ZV. Nizozemské kurikulum vykazuje v porovnání s RVP ZV vyšší míru vnitřní koherence i návodnosti, švédské kurikulum vykazuje vyšší míru vnitřní koherence a obdobnou míru návodnosti. I přes nižší míry obou sledovaných faktorů kvality, které NC v porovnání s výše zmíněnými dokumenty vykazuje, může být zdrojem pro poučení při revizích RVP ZV. 


\section{Literatura}

Annerstedt, C. (2008). Physical education in Scandinavia with a focus on Sweden: A comparative perspective. Journal Physical Education and Sport Pedagogy, 13(4), 303-318.

Bereday, G. Z. (1966). Comparative method in education. New York: Holt, Rinehart and Winston.

CMO. (2011). UK physical activity guidelines. Dostupné z https://www.gov.uk/government/ publications/uk-physical-activity-guidelines

Crum, B. (2017). How to win the battle for survival as a school subject? Reflections on justification, objectives, methods and organization of PE in schools of the 21st century. In Retos: Nuevas tendencias en educación física, deportes y recreación, 31(2017), 238-244.

DfE. (2013). The national curriculum in England: Key stages 1 and 2 framework document. Dostupné z https://assets.publishing.service.gov.uk/government/uploads/system/ uploads/attachment_data/file/425601/PRIMARY_national_curriculum.pdf

DfE. (2017). Statutory framework for the early years foundation stage Setting the standards for learning, development and care for children from birth to five. Dostupné $\mathrm{z}$ https://assets. publishing.service.gov.uk/government/uploads/system/uploads/attachment_data/ file/596629/EYFS_STATUTORY_FRAMEWORK_2017.pdf

DfE. (2017). National curriculum: Phisical education: Analysis of progression across the Key Stages. Dostupné z http://www.afpe.org.uk/physical-education/wp-content/uploads/ NCfinalprogressionmapoverview-1.pdf

Dvořák, D., Holec, J., \& Dvořáková, M. (2018). Kurikulum školního vzdělávání: zahraniční reformy v 21. století. Praha: Univerzita Karlova.

Egger, K., J., Khnis, B., Nussbaum, P., \& Dniken, P. (2002). Qualität des Sportunterrichts: Projektbericht. Bern: Schriftenreihe des Instituts für Sport und Sportwissenschaft der Universität Bern.

Eurybase. (2010). Organisation of the education system in the United Kingdom - England, Wales and Northern Ireland. Dostupné z https://www.exeter.ac.uk/media/universityofexeter/ collegeofsocialsciencesandinternationalstudies/education/pgce/pre-coursedocuments/ pre-coursedocuments2017-18/Secondary_MFL_-_Eurydice_explanation_of_the_English_ education_system.pdf

Eurydice. (2018). United Kingdom - England overview. Dostupné z https://eacea.ec.europa.eu/ national-policies/eurydice/content/united-kingdom-england_en

Fisher, R. (2005). Physical education in England. In U. Pühse \& M. Gerber (Eds.), International comparison of physical education: concepts, problems, prospects (s. 460-471). Oxford: Meyer \& Meyer Sport.

GOV.UK. (2018). Types of school. Dostupné z https://www.gov.uk/types-of-school

Habrdlová, M., \& Vlček, P. (2015). Srovnání kurikula tělesné výchovy pro primární vzdělávání v Irsku a České republice. Česká kinantropologie, 19(4), 34-48.

Habrdlová, M., Lupač, M., \& Vlček, P. (2017). Srovnání obsahu vybraných kurikulárních dokumentů tělesné výchovy pro primární vzdělávání v Irsku, Nizozemsku a České republice. Pedagogická orientace, 27(3), 449-472.

Hardman, K., \& Parry, G. (2015). Physical education in England. In P. D. Pavlovic, N. Zivanovic, B. Antala, \& K. M. Pantelic Babic (Eds.), History of physical education in Europe II (s. 144-179). Leposavic: University of Pristina, FIEP Europe.

Hendl, J. (2005). Kvalitativní výzkum: základní metody a aplikace. Praha: Portál. 
HM Government. (2015). Sporting future: A new strategy for an active nation. Dostupné z https:// assets.publishing.service.gov.uk/government/uploads/system/uploads/attachment_ data/file/486622/Sporting_Future_ACCESSIBLE.pdf

Hoffmann, D., Brixius, K., \& Vogt, T. (2018). Racket sports teaching implementations in physical education - a status quo analysis of German primary schools. Journal of Physical Education and Sport, 18(2), 867-873.

Holmes, B. (1965). Problems in education. A comparative approach. London: Routledge and Kegan Paul.

Holmes, B. (1981). Comparative education: Some consideration of method. London: Unwin Hyman.

Ignas, E., Corsini, R. J., Anderson, R. S., Estrada, L. J., Hawkins, J. N., Holmes, B., ... \& Taylor, P. H. (1981). Comparative education systems. Itasca: Peacock Publishers.

Janík, T., Maňák, J., Knecht, P., \& Němec, J. (2010). Proměny kurikula současné české školy: vize a realita. Orbis Scholae, 4(3), 9-35.

Janík, T., Knecht, P., \& Kubiatko, M. (2011). Kvalita školy a kurikula: od expertního šetrení ke standardu kvality. Praha: Výzkumný ústav pedagogický.

Janík, T., Mužík, V., \& Vlček, P. (2016). Implementace kurikulární reformy v České republice: obecné problémy konkretizované pohledem na kurikulum tělesné výchovy. In Š. Porubský et al. (Eds.), Premeny školského kurikula: slovenská a česká skúsenost' (s. 131-141). Banská Bystrica: Belianum.

Ježková, V., Dvořák, D., Chapman, Ch., Boyle, B., Gunter, H., \& Dyson, A. (2010). Školní vzdělávání ve Velké Británii. Praha: Karolinum.

Jin, A. (2013). Physical education curriculum reform in China: A perspective from physical education teachers. Physical Education and Sport Pedagogy, 18(1), 15-27.

Kelly, A. V. (1987). Education. London: Heinemann.

Kirk, D. (1992). Defining physical education: The social construction of a school subject in postwar Britain. London: Falmer Press.

Kougioumtzis, K. (2014). The experienced physical education curriculum: A comparative study of primary and lower secondary school pupils in Sweden and South Africa. Göteborg: University of Gothenburg.

Lupač, M. (2016). Obsahová analýza kurikulárních dokumentů tělesné výchovy v Nizozemsku z hlediska vybraných faktorů kvality projektovaného kurikula: komparace s RVP ZV. Studia Sportiva, 10(1), 15-32.

Lupač, M. (2017). Vývoj výzkumného nástroje pro komparaci kurikulárních dokumentů tělesné výchovy. In P. Fořterová-Matoušková \& J. Chrudimský (Eds.), Fórum kinantropologie 2017 (s. 71-83). Praha: Univerzita Karlova.

Lupač, M. (2018). Analýza projektovaného kurikula TV ve Švédsku: komparace s RVP ZV. Tělesná kultura, 41(1), 25-41.

Manzon, M. (2007). Comparing places. In M. Bray, B. Adamson \& M. Mason (Eds.), Comparative education research: approaches and methods (s. 85-123). Hong Kong: Comparative education research centre, The University of Hong Kong.

MŠMT. (2017). Rámcový vzdělávací program pro základní vzdělávání. Dostupné z http://www. msmt.cz/file/43792_1_1/

Naul, R. (2003). Koncepce školní tělesné výchovy v Evropě. Česká kinantropologie, 7(1), 39-53. 
Naul, R. (2011). Conceptual diversity and future directions of physical education in the global context. Japanese Journal of Sport Education Studies, 30(2), 39-50.

NHS Digital. (2018). Statistics on obesity, physical activity and diet: England: 2018. Dostupné $\mathrm{z}$ https://files.digital.nhs.uk/publication/0/0/obes-phys-acti-diet-eng-2018-rep.pdf

Noah, H., \& Eckstein, M. (1969). Towards a science of comparative education. London: Macmillan.

ONS. (2012). 2011 Census: Key statistics for local authorities in England and Wales. Dostupné z http://www.ons.gov.uk/ons/rel/census/2011-census/key-statistics-for-local-authoritiesin-england-and-wales/rft-table-ks209ew.xls

Polívka, P. (Ed.). (2016). Metodické komentáře a úlohy ke Standardům pro základní vzdělávání: Tělesná výchova. Praha: NúV.

Rada Evropy. (1992). Evropská charta sportu. Dostupné z http://www.cuscz.cz/files/291NjZ.pdf

Rossi, T., Tinning, R., McCuaig, L., Sirna, K., \& Hunter, L. (2009). With the best of intentions: A critical discourse analysis of physical education curriculum materials. Journal of Teaching in Physical Education, 28(1), 75-89.

Seeley, L. (1904). History of education. Dostupné $\mathrm{z}$ http://www.gutenberg.org/ files/27963/27963-h/27963-h.htm

Skolverket.(2011).Curriculum for the compulsoryschool, preschoolclass and theleisure-time centre 2011. Dostupné z http://malmo.se/download/18.29c3b78a132728ecb52800034181/ pdf2687.pdf

Šíp, R. (2014). Problematické aspekty současné pedagogiky z pohledu pedagogické filozofie: vztah praxe a teorie a potlačení somatické dimenze pedagogických procesů (Habilitační práce). Dostupné z https://is.muni.cz/do/rect/habilitace/1441/Sip/habilitace/Sip_Habilitacni_ prace_FIN.pdf

Tupý, J. (2018). Tvorba kurikulárních dokumentů v České republice: Historicko-analytický pohled na prípravu kurikulárních dokumentů pro základní vzdělávání v letech 1989-2017. Brno: Masarykova univerzita.

Vlček, P., \& Janík, T. (2010). Školské reformy a tvorba kurikula tělesné výchovy v České republice, Spolkové republice Německo a Spojených státech amerických: Pedagogický výzkum v teorii a praxi. Brno: Paido.

Wallace, S. (2015). Dictionary of education. Oxford: Oxford University Press.

WHO. (2013). Infographic. Dostupné z http://www.euro.who.int/_data/assets/pdf file/0011/256295/infographic-people-overweight-obese-Eng.pdf?ua=1

WHO. (2014). Infographic. Dostupné z http://www.euro.who.int/_data/assets/pdf_ file/0005/254993/Infographic-1-in-3-children-overweight-Eng.pdf?ua=1

WHO. (2016). Photo gallery - world statistics day 2016. Dostupné z http://www.euro.who.int/ en/health-topics/noncommunicable-diseases/obesity/data-and-statistics/photo-galleryworld-statistics-day-2016

WHO. (2017). Health survey for England 2016: Adult overweight and obesity. Dostupné z https:// files.digital.nhs.uk/publication/m/6/hse2016-adult-obe.pdf

WHO. (2018). Obesity. Dostupné z http://www.who.int/topics/obesity/en/

Zhu, X., Ennis, C. D., \& Chen, A. (2011). Implementation challenges for a constructivist physical education curriculum. Physical Education and Sport Pedagogy, 16(1), 83-99. 


\title{
Autor
}

Mgr. Michal Lupač, Masarykova univerzita, Pedagogická fakulta, Katedra tělesné výchovy a výchovy ke zdraví, Poříćí 31, 60300 Brno, e-mail: lupac@mail.muni.cz

\section{Physical Education in England: The Comparison with the Czech Curriculum}

\begin{abstract}
The paper focuses on the analysis of the designed PE curriculum in England and its comparison with the Czech curriculum in terms of PE conception, aims, educational content and chosen qualitative factors - instructional quality and internal coherence. To address the issue in a wider context, the text offers a brief excursion into the educational system in England. Selection of the states was based on the Naul's PE concepts definition (2011, p. 9), according to which the PE conception in England tends to the sport conception. Naul, however, uses the data from the 1990s, so it is one of the goals of the study to verify whether this conceptual direction remains valid.

The study was designed according to the problem approach and the comparative method. For the data collection we used the content text analysis. The results indicate that the English designed PE content tends towards the sport conception. This is, however, in a modest contradiction with the aims, which are also partly aimed towards the sport conception. The life-long physical activity as the goal of English PE is also strongly pronounced. This inconsistency partly affects the internal coherence of the document. The aims are also designed very broadly but some of them are not supported by adequate educational content. From the instructional quality point of view, we can state that the English PE document is not as instructive as the Czech Framework educational programs. The Czech designed PE content is wider and deeper.
\end{abstract}

Key words: England, curriculum, physical education, instructional quality, internal coherence, comparison 